Cuadernos de Investigación Geográfica. Tomo IX-1983 - págs. 3-14

(C) Colegio Universitario de La Rioja - Logroño

\title{
PROBLEMS OF THE DYNAMICS OF SOME ROMANIAN RIVER CHANNELS
}

\author{
Ioniţă Ichim* \\ Dan Batuca** \\ María Radoane*
}

\begin{abstract}
RESUMEN
El presente trabajo pretende discutir la dinámica de algunas secciones transversales de varios ríos situados bajo diferentes condiciones de caudal, carga de sedimentos, tamaño de los depósitos del lecho, tipo de cauce e intervención antrópica.

En cortos intervalos de tiempo caracterizados por elevadas crecidas y ciclos estacionales, se ha comprobado una alternancia de agradación e incisión cuya amplitud puede ir más allá de 1-1,5 m. Para largos intervalos de tiempo (años) destacamos la alternancia de fenómenos de agradación y degradación con una amplitud de hasta 2-3 m. e incluso más.

Evaluamos también las condiciones de la estabilidad morfológica de los cauces, obteniendo exponentes de la descarga en una estación con un relativamente amplio espacio de variación.
\end{abstract}

\section{SUMMARY}

Our present work is meant to discuss the dynamics in some cross-sections of several rivers situated in different conditions: discharge and load, grain size channel deposits, slope, channel pattern, anthropic intervention.

For the short intervals of time characteristics for high floods and season cycles, there has been noticed an alternation of "fill" and "scour" on an amplitude which may go beyond 1-1,5 m.

For the longer intervals of time (years) we noticed the alternation of the aggradation and degradation phenomena with a maximal amplitude up to 2-3 $m$. and even more.

* Geomorph. Lab. Res. Station. Pîngarati, 5648, Neamt, Rumania.

${ }^{* *}$ Hydraulic Engineering Res. Inst., Bucarest, Rumania. 
We also evaluated the conditions of morphological stability of the channels, obtaining exponents of the discharge-at a station with a relatively large space of variation.

\section{Introduction}

Romania's territory has a surface of $237.500 \mathrm{~km}^{2}$ and a river network with a total length of more than $60.000 \mathrm{~km}$. This is, almost exhaustively, tributary to the Danube. Some specific conditions control the dynamics of these channels, namely: the position of the territory being in temperate-continental climate (with different nuances), an evident leveling of morphoclimatic conditions from the steppes to the alpin belt, inclusively; the variety of lithological structure; recent crustal movements with a yearly amplitude of about $10 \mathrm{~mm}$. (+6 mm./year in the northern-central part of the Eastern Carpathians, and $-4 \mathrm{~mm} /$ year in Tara Bîrsei); a complex anthropic influence in morphogenesis (dam-building, river regulation, irrigation and urban needs, etc.).

The flow regime is, with few exceptions, characterized by high floods well marked in every season (DIACONU et al., 1971); about $85 \%$ of the yearly flow volume is produced in the mountaineous area, which covers $30 \%$ of the country's territory. In the extra-carpathians area there are important drainage basins (some having a surface of over $3.000 \mathrm{~km}^{2}$ ) in which the rivers may dry up at least one time in 2-3 years. In the multi-yearly flow variation one can identify, on the main rivers, a certain cyclic reccurence at about 9-12 years.

\section{Anterior researchs}

The channel dynamics of Romania rivers was the aim of many specialists in reclamations problems and many geographers already for a long time. Thus, in the XVIII-th century, on the occasion of elaborating desings for the rivers Dîmboviţa, Sabar and of the Bega canal, the first thorough examination had been made. We won't make a history of such researchs. We can, though, remark the peculiar attention payed in the last 25-30 years when the bases of field experimental researchs had been larged. We shall mention some of the contributions that are based on long series of field measurements (URZICEANU-ROŞCA, 1971, 1973; DIACONU et al, 1962; DIACONU, 1971; HÎNCU, 1976;BĂTUCĂ, 1978, 1979; SEIBULESCU et al., 1970; BONDAR \& PAPADOPOL, 1973; ICHIM \& RĂDOANE, 1980).

The investigations made up to now show that, in the complex of conditions presented by Rumania, we are in a region with intense channel proces- 


\section{DYNAMICS OF ROMANIAN RIVERS}

ses. Important lateral shifting are mentioned, especially on the big sub-carpathian and extra-carpathian valleys. To identify some evolutional tendencies we took under study more cross-sections situated in different physiographical conditions (table 1).

TABLE 1

Some features on cross sections analysed.

\begin{tabular}{|c|c|c|c|c|c|c|c|}
\hline River & $\begin{array}{l}\text { Cross } \\
\text { section }\end{array}$ & $\begin{array}{r}\text { Drainage } \\
\text { area }_{\mathrm{km}} \\
\end{array}$ & $\begin{array}{l}\text { Discharge } \\
\mathrm{m}^{3} / \mathrm{s}\end{array}$ & $\begin{array}{l}\text { Channel } \\
\text { deposits }\end{array}$ & $\begin{array}{l}\text { Conditions } \\
\text { of present } \\
\text { evolution }\end{array}$ & $\begin{array}{l}\text { Period } \\
\text { (Years) }\end{array}$ & Source \\
\hline $\begin{array}{l}\text { Bîrlad } \\
\text { Moldova } \\
\text { Bistrița } \\
\text { Jijia } \\
\text { olt } \\
\text { Oîmbovita } \\
\text { Ilișua } \\
\text { Rusca } \\
\text { Arges }\end{array}$ & $\begin{array}{l}\text { Vaslui I } \\
\text { Vaslui II } \\
\text { Birlad } \\
\text { Tecuci } \\
\text { Tupilati } \\
\text { Frumosu } \\
\text { Dorohoi } \\
\text { Todireni } \\
\text { Feldioara } \\
\text { Contesti } \\
\text { Cristeștii } \\
\text { Ciceului } \\
\text { Rusca } \\
\text { Budești }\end{array}$ & $\begin{array}{c}817 \\
817 \\
3952 \\
6778 \\
4028 \\
2816 \\
255 \\
1080 \\
5614 \\
1054 \\
70 \\
163 \\
9365\end{array}$ & $\begin{array}{c}2.37 \\
2.37 \\
3.37 \\
9.01 \\
31.8 \\
32.5 \\
0.39 \\
1.36 \\
32.20 \\
11.20 \\
3.28 \\
4.57 \\
40.00\end{array}$ & $\begin{array}{c}\text { sand } \\
\text { ", } \\
\text { "' } \\
\text { gravel } \\
\text { ". } \\
\text { sand } \\
15 \mathrm{~mm} \\
\text { gravel } \\
\text { " } \\
\text { boulder } \\
\text { sand }\end{array}$ & $\begin{array}{c}\text { natural } \\
\text { arranged } \\
\text { natural } \\
\text { arranged } \\
\text { natural } \\
\text { " } \\
\text { " } \\
\text { "' } \\
\text { " } \\
\text { " } \\
\text { " }\end{array}$ & $\begin{array}{c}1976-78 \\
1973-77 \\
1963-78 \\
1972-78 \\
1963-78 \\
1967-78 \\
1968-79 \\
1 " \\
1957-67 \\
1959-69 \\
1957-68 \\
1957-67 \\
1965-68\end{array}$ & $\begin{array}{l}\text { Rădoane } \\
\text { Amáriucai } \\
\text { \& Ichim } \\
\text { (1980) } \\
" \\
. \\
\text { ". } \\
\text { Urziceanu, } \\
\text { Roșca(1971) } \\
\text { ". } \\
\text { ". }\end{array}$ \\
\hline
\end{tabular}

\section{Cross-section dynamics in short times (problems of scour and fill processes).}

Analysing the exemplified channel cross-sections, we mainly took into account the changing of the talweg elevation as to refference plan considered the zero plan of the rod.

Reworking daily measurements made in periods up to 18 years, we learned that the amplitude of the bed hight variation, in short time, had come to 1.5-2 m., and sometimes even over $3 \mathrm{~m}$. It is an amplitude which is comparable to that which Leopolod at al. (1964) gave for channels with semi-arid conditions. In our case, such fluctuations are the expression of climatic continentalism, with influence on the high flood flow. No matter their genetical signification, there fluctuations introduce wide scatter of the correlation points on the basis of which the regime equations are obtained, a fact that could invalidate, in some cases, the attempt to define on this way the hydraulic geometry of a given cross-section (KNIGHTON,) 1977: Rădonne et al. 1980).

The mecanism of producing the scour-fill phases, in one and same section, is generally known. But the problems of succesion of such phases alongside the river remains an unanswered questions. The investigations performed up to new give different answers to this problems, answers that are often con- 
tradictory: LANE \& BORLAND (1954), LEOPOLD et al. (1964), COLBY (1964), ANDREWS (1979). In Romania, URZICEANU-ROŞCA (1971) noticed that with the flood of may-june, 1970 "in channels, heavy erosion processes were produced on the whole length of the river" (p. 194). At the same time, the total volume of the alluvial deposits brought by the Danube into the Black Sea was much more reduced that the volume resulted from river-section scour, without adding the volume of the slope sediments. Thus the following question arises: where were the great quantities of alluvial deposits resulted from river-section scour accumulated? As to such phenomena noticed in other parts, different opinions have been expressed.

We think that in short time (minutes; hours, days or seasons) the channel dynamics, at least on certain reachs, represents a succession of situations between scour-fill: scour is dominant during high flood, and fill during lower flow. We do not consider this observations as a fully satisfactory answer. The cause of not exactly knowing the mentioned phenomena is due to the lack of detailed researchs made in long period of time on the longitudinal profile.

\section{Cross-section dynamics in long time (problems of aggradation and degradation processes)}

To appreciate long time channel dynamics (MACKIN, 1948, p. 471), refers to "periods of many years") we took into account the defining of the grade condition for some Romanian rivers. To this purpose we analysed:

The daily data regarding channel bed elevation and discharge by means of filtering method. Thus, we obtained 30 days and 6 month-moving means which may graphically be represented by means of sinusoidal curves. This phenomenon is common both for natural and for man-made cross-sections (fig. 1, 2, 3).

The balance of scour and fill processes determined for 600 time cross sections of the Bîrlad river channel. The obtained results permitted thes following conclusions:

In long time, with the same cross section, a river channel bed presents an altenation of degradation cycles with aggradation cycles. This reality is clearly expressed by calculating the scour-and-fill balance in a long period of time. In table 2, we exemplify a model of balance calculation, in which we chose three moments of the Bîrlad river channel dynamics in the period 1969-1978: negative balance, zero and positive. The cycle length was, on an average, of 11 years: between 1958 and 1969 there was a degradation cycle, and between 1969 and 1979 there was an aggradation cycle.

The ralatively simultaneous presence of degradation and aggradation cycles. The phenomenon was evidentiated for 59 analysed river sections, from 
the whole of Romania's territory, on periods of 30-40 years (after the data published by DIACONU et al 1962; URZICEANU-ROŞCA, 1.971).

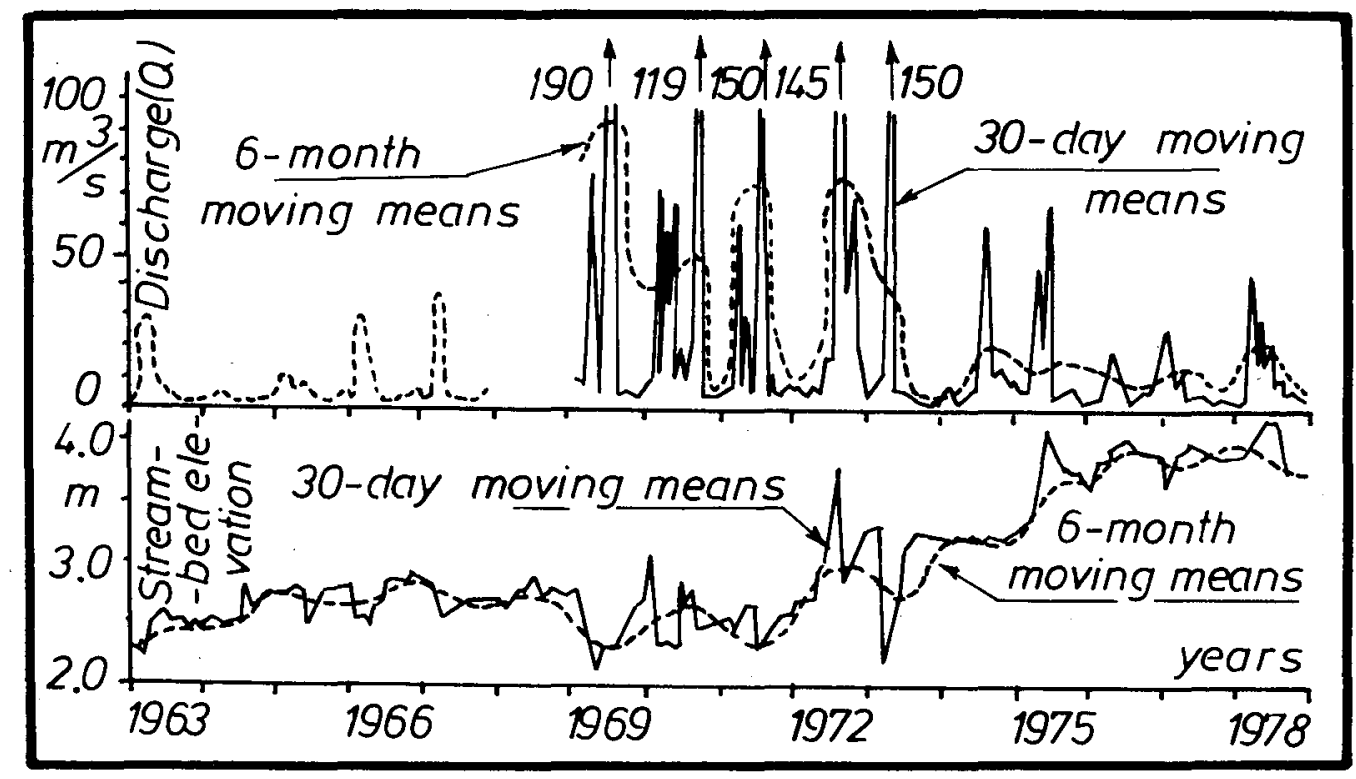

FIG. 1

Streambed dynamics of Bîrlad river at Bîrlad cross section.

The long term fluctuations of channel bed dynamics almost truely expresses the flow fluctuations, in which the cycles of high flow approximately coincide with the aggradation cycles and the cycles of low flow with degradation cycles. This is one more proof that the cyclicity of natural phenomena, often mentioned in scientific literature (DIACONU, 1973; ROVENTA \& NICOLAE, 1975) also has repercussion long term channel dynamics. We are not intended to have a special discussion on the mechanism of cycle producing, their spacial development, with the part played by load, and others. We only wont to show that the three statements may offer a real image on the manifestation of the grade condition for some Romanian rivers. This is shown by the succession of the oscillation imposed by de gradation-aggradation, with an amplitude, for the analysed cases, of 2,5-3 m., which include the oscillations imposed by scour and fill. Of course, introducing these elements into the morphometric relations to calculate channel dimensioning and regulation, may offer new reference points of interpretation of the evolutional tendencies on long time, aspect we shall later recall into attention. 
IONITA ICHIM, DAN BATUCA, MARIA RADOANE

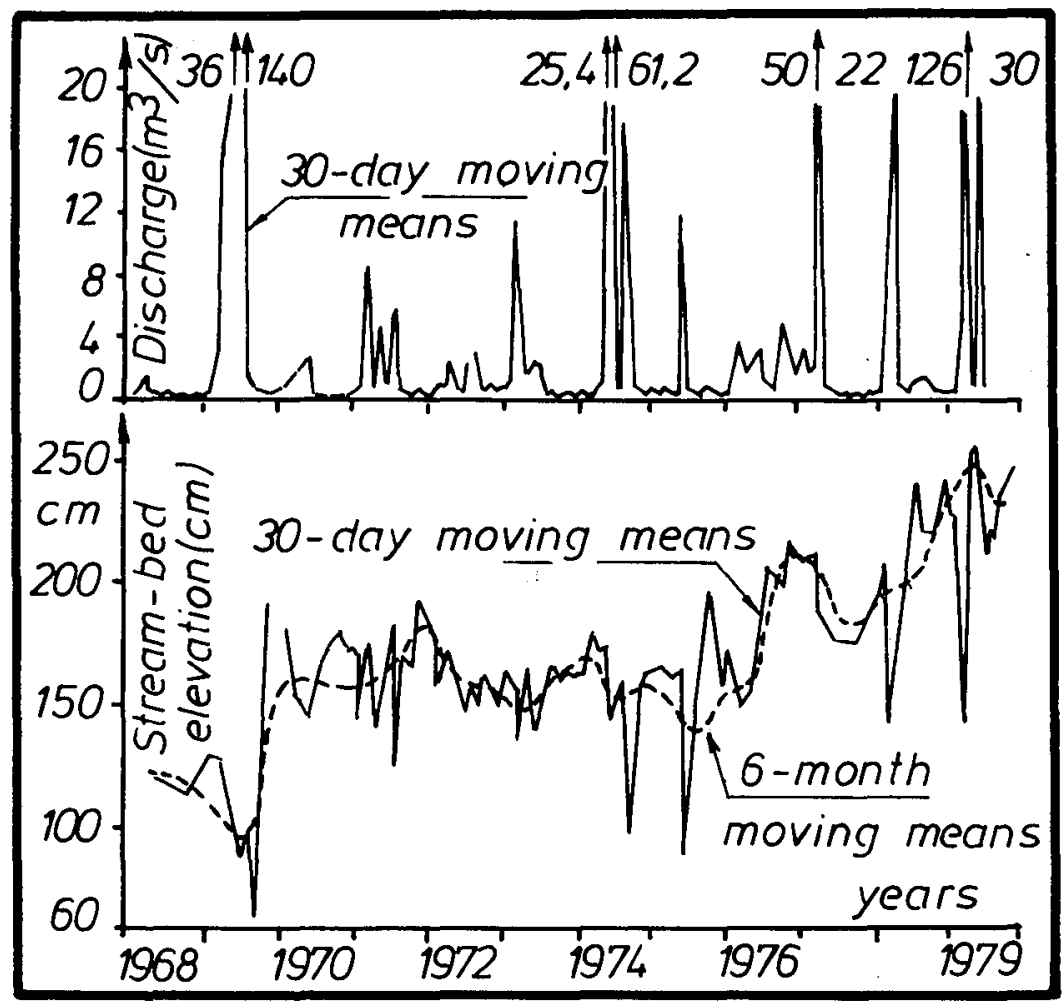

FIG. 2

Streambed dynamics of Jijia river at Dorohoi cross-section.

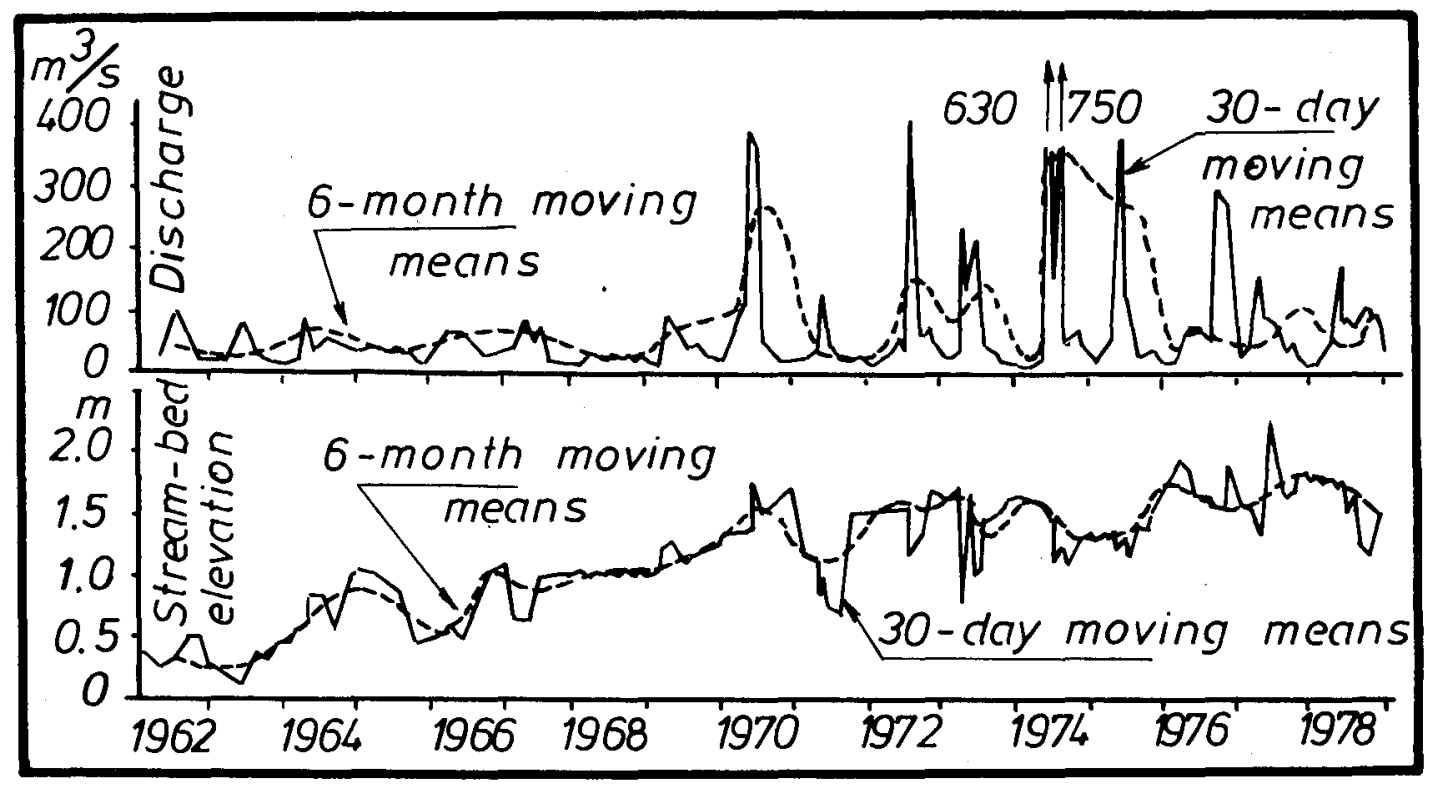

FIG. 3

Streambed dynamics of Moldova river at Tupilati cross section. 


\section{DYNAMICS OF ROMANIAN RIVERS}

\section{The problem of morphological channel stability}

In the conditions of heavy dynamics in Romanian channels, for arrangements of hydrotechnic constructions, canals, irrigations, it is necessary to identify the conditions of morphological stability. The literature of channel engineering is concerned to establish the theoretical morphometric relations which should, as truely as possible, check channel behavior on long periods.

To this, one proceeded to statistically remake the hydrometric data collected from channel sections which showed no important modifications along many years (1971-1979). Morphometric relation of the regime equation type have been worked out (LEOPOLD \& MADDOCK, 1953), of semiempiric equation type (VELIKANOV, 1958), and morphometric relations that explain the hydraulic resistancy of morphologically stable channels. These morphometric relations were established both for the physiographical conditions characterizing the drainage basins of Up per Mureş (Tîrnava Mică, Tîrnava Mare and Mureş rivers) and for the generalized form minding the hydrometric data of other Romanian streams (Jiu, Someş, Bîrlad, Lower Mureş) and, comparatively for a number of 18 canals from the SardaYamuna-Ganga irrigation systems of India, the latest published by GUPTA et al. 1966 (cf. BĂTUC $\breve{A}, 1979$ ).

TABLE 2

Samples of erosion-accumulation balance Bîrlad river channel (Bîrlad cross section) in periode 1969-1975.

\begin{tabular}{|c|c|c|c|c|c|c|c|c|}
\hline \multirow[b]{3}{*}{ Date } & \multirow{3}{*}{ 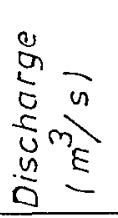 } & \multirow{3}{*}{ 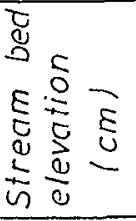 } & \multicolumn{6}{|c|}{ Erosion-accumulation balance $\left(\mathrm{m}^{3} / \mathrm{unit}\right.$ of channel lenght) } \\
\hline & & & left & bank & right & bank & all cross & section \\
\hline & & & $\begin{array}{l}\text { half cross } \\
\text { section } \\
\text { values }\end{array}$ & $\begin{array}{l}\text { cumulated } \\
\text { values }\end{array}$ & $\begin{array}{l}\text { half cross } \\
\text { section } \\
\text { values }\end{array}$ & $\begin{array}{l}\text { cumulated } \\
\text { values }\end{array}$ & $\begin{array}{l}\text { all cross } \\
\text { section } \\
\text { values }\end{array}$ & $\begin{array}{l}\text { cumulated } \\
\text { values }\end{array}$ \\
\hline $\begin{array}{l}\frac{1969}{10.06} \\
11.06 \\
14.06 \\
18.06 \\
23.06\end{array}$ & $\begin{array}{l}7.18 \\
5.00 \\
7.44 \\
3.13 \\
1.66\end{array}$ & $\begin{array}{l}215 \\
220 \\
232 \\
228 \\
231\end{array}$ & $\begin{array}{l}+0.43 \\
+0.50 \\
+1.85 \\
+0.68 \\
+0.65\end{array}$ & $\begin{array}{l}-22.80 \\
-22.30 \\
+20.45 \\
-29.77 \\
-19.12\end{array}$ & $\begin{array}{l}+0.23 \\
+0.16 \\
+0.49 \\
+0.33 \\
+0.80\end{array}$ & $\begin{array}{l}-2.73 \\
-2.57 \\
-2.08 \\
-2.05 \\
-1.25\end{array}$ & $\begin{array}{l}+0.66 \\
+0.66 \\
+2.34 \\
+1.01 \\
+1.45\end{array}$ & $\begin{array}{l}-25.51 \\
-24.85 \\
-22.51 \\
-21.15 \\
-20.05\end{array}$ \\
\hline $\begin{array}{r}\frac{1973}{18.07} \\
23.07 \\
31.07 \\
6.08 \\
8.08\end{array}$ & $\begin{array}{l}4.80 \\
2.78 \\
2.85 \\
5.64 \\
2.27\end{array}$ & $\begin{array}{l}325 \\
320 \\
321 \\
328 \\
322 \\
\end{array}$ & $\begin{array}{l}+4.18 \\
+1.73 \\
+1.83 \\
+0.16 \\
+0.02\end{array}$ & $\begin{array}{l}+6.14 \\
+7.87 \\
+9.70 \\
+9.86 \\
+9.88\end{array}$ & $\begin{array}{l}+1.28 \\
-0.08 \\
+0.31 \\
+0.02 \\
+0.02\end{array}$ & $\begin{array}{l}-7.76 \\
-7.84 \\
-7.53 \\
-7.51 \\
-7.49\end{array}$ & $\begin{array}{l}+5.38 \\
+1.65 \\
+2.14 \\
+0.18 \\
+0.04\end{array}$ & $\begin{array}{l}-1.62 \\
+0.03 \\
+2.17 \\
+2.35 \\
+2.39\end{array}$ \\
\hline$\left[\begin{array}{c}\frac{1975}{27.11} \\
2.12 \\
5.12 \\
8.12 \\
11.12\end{array}\right.$ & $\begin{array}{r}0.07 \\
1.27 \\
8.46 \\
15.80 \\
8.74\end{array}$ & $\begin{array}{l}365 \\
361 \\
369 \\
344 \\
363\end{array}$ & $\begin{array}{l}+0.49 \\
-0.05 \\
+0.02 \\
-3.56 \\
+7.50\end{array}$ & $\begin{array}{l}+16.40 \\
+16.35 \\
+16.37 \\
+12.71 \\
+20.21\end{array}$ & $\begin{array}{l}+0.04 \\
+0.18 \\
+0.32 \\
-0.97 \\
+1.40\end{array}$ & $\begin{array}{l}+0.26 \\
+0.08 \\
+0.40 \\
-0.57 \\
+0.63\end{array}$ & $\begin{array}{l}+0.53 \\
-0.23 \\
+0.40 \\
-4.53 \\
+8.40\end{array}$ & $\begin{array}{l}+16.60 \\
+16.37 \\
+16.77 \\
+12.24 \\
+20.61\end{array}$ \\
\hline
\end{tabular}

Note: (+) accumulation; (-) erosion. 
IONITA ICHIM, DAN BATUCA, MARIA RADOANE

Empiric regime equations. For the conditions proper to the natural streams to the Upper Mureş drainage basin, we specify the following downstream empirical equations of the exponential type of the regime equations, for two categories of alluvial stable channels:

a) Channels having the banks and bed made up of fine and middle sized sandy materials:

$$
\begin{aligned}
& \mathrm{A}=1.95 \mathrm{Q}^{0.805} \\
& \mathrm{~V}_{\mathrm{m}}=0.513 \mathrm{Q}^{0.195} \\
& \mathrm{~B}=3.00 \mathrm{Q}^{0.506} \\
& \mathrm{~h}_{\mathrm{m}}=0.65 \mathrm{Q}^{0.300} \\
& \mathrm{~B} / \mathrm{h}_{\mathrm{m}}=4.62 \mathrm{Q}^{1 / 5}
\end{aligned}
$$

b) Channels having the banks made up of fine and middle sized sandy materials, but materials:

$$
\begin{aligned}
& \mathrm{A}=0.60 \mathrm{Q}^{0.805} \\
& \mathrm{~V}_{\mathrm{m}}=1.667 \mathrm{Q}^{0.195} \\
& \mathrm{~B}=1.02 \mathrm{Q}^{0.506} \\
& \mathrm{~h}_{\mathrm{m}}=0.56 \mathrm{Q}^{0.300} \\
& \mathrm{~B} / \mathrm{h}_{\mathrm{m}}=1.73 \mathrm{Q}^{1 / 5}
\end{aligned}
$$

in which $\mathrm{Q}=$ bankfull discharge, and $\mathrm{A}=$ cross section area, $\mathrm{V}_{\mathrm{m}}=$ average velocity of the water current, $B=$ channel width, $h_{m}=$ average depth, are the elements from the bankfull.

Generalizing these morphometric relations to a number of Romanian suplimentary rivers, as much as, to the irrigation canals of India determined us to extend them over to the following three channel categories:
a) Channels with sandy river banks and the bed of small and fine sandy materials:

$$
\begin{array}{ll}
\mathrm{A}=2.00 \mathrm{Q}^{0.840} & \mathrm{~A}=\mathrm{Q}^{0.840} \\
\mathrm{~V}_{\mathrm{m}}=0.50 \mathrm{Q}^{0.160} & \mathrm{~V}_{\mathrm{m}}=\mathrm{Q}^{0.160} \\
\mathrm{~B}=3.25 \mathrm{Q}^{0.540} & \mathrm{~B}=2.00 \mathrm{Q}^{0.540} \\
\mathrm{~h}_{\mathrm{m}}=0.615 \mathrm{Q}^{0.300} & \mathrm{~h}_{\mathrm{m}}=0.50 \mathrm{Q}^{0.300} \\
\mathrm{~B} / \mathrm{h}_{\mathrm{m}}=5.285 \mathrm{Q}^{0.240} & \mathrm{~B} / \mathrm{h}_{\mathrm{m}}=4.00 \mathrm{Q}^{0.240}
\end{array}
$$

b) Channels with sandy river banks and the bed of small and middle sized sandy materials:

c) Channels with sandy river banks and the bed of middle sized and big sandy materials:

$$
\begin{array}{cc}
\mathrm{A}=0.50 \mathrm{Q}^{0.840} & \mathrm{~V}_{\mathrm{m}}=2.00 \mathrm{Q}^{0.160} \\
\mathrm{~B}=1.20 \mathrm{Q}^{0.540} & \mathrm{~h}_{\mathrm{m}}=0.415 \mathrm{Q}^{0.300} \\
\mathrm{~B} / \mathrm{h}_{\mathrm{m}}=2.892 \mathrm{Q}^{0.240}
\end{array}
$$

The whole of these results is in full agreement with those of other researchers: LACEY, BLENCH, NIXON, LEOPOLD, MADDOCK SIMONS, ALBERTSON, RÎBKIN, LEVI, ACKERS, obtained on other geographical areas of the earth. 


\section{DYNAMICS OF ROMANIAN RIVERS}

Semiempiric equations. Considering a large number of physical parameters that determine a regime of morphological stability of the alluvial channels of the waterways, permitted for the rivers of the Upper Mureş drainage basin, the development of the following morphometric relations with a semiempiric character of the VELIKANOV (1958):

$$
\frac{\mathrm{B}}{\mathrm{d}}=1.565\left(\frac{\mathrm{Q}}{\mathrm{d}^{2} \sqrt{\mathrm{gdJ} J}}\right)^{0.434 ;} \quad \frac{\mathrm{h}_{\mathrm{m}}}{\mathrm{d}}=0.113\left(\frac{\mathrm{Q}}{\mathrm{d}^{2} \sqrt{\mathrm{gdJ}}}\right)^{0.391}
$$

in which suplimentary notations signify: $\mathrm{g}=$ the acceleration of gravity; $\mathrm{J}=$ hydraulic slope, and $\mathrm{d}=\mathrm{d}_{50}=$ the $50 \%$ diameter of alluvial particles from the channel bed.

Morphometric equations of channel hydraulic resistency. To express in an analytical form the hydraulic resistency of channels, through a statistical rework of hidrometric data, we established the following morphometric equation types:

$$
\begin{aligned}
& \mathrm{n}=0.030 \mathrm{~d}_{50}{ }^{1 / 6} \\
& \mathrm{~V}_{\mathrm{m}}=1.30 \mathrm{~h}_{\mathrm{m}}{ }^{3 / 4} \\
& \mathrm{~V}_{\mathrm{m}}=0.90 \mathrm{~h}_{\mathrm{m}}{ }^{2 / 3} \mathrm{j}^{1 / 3} \\
& \frac{\mathrm{V}_{\mathrm{m}}}{\sqrt{\frac{\rho \mathrm{s}-\rho}{\rho} \mathrm{gd}}}=3.20 \frac{\mathrm{h}_{\mathrm{m}}^{2 / 3}}{\mathrm{~d}} \sqrt{\frac{\rho \mathrm{J}}{\rho \mathrm{s}-\rho}}
\end{aligned}
$$

for channels having beds of alluvial materials with $\mathrm{d}_{50}=0.2-0.6 \mathrm{~mm}$; for channels having beds of alluvial materials with $\mathrm{d}_{50}=0.6-2 \mathrm{~mm}$;

characteristic for the rivers Tîrnava Mică, Tîrnava Mare and Mureş, from the Upper Mureş drainage basin, in which the suplimentary simbols signify: $\mathbf{n}=$ the Manning rugosity coefficient $\mathbf{J}=$ slope in $\% 0, \mathrm{~s}, \quad=$ alluvial material density and water density respectively.

\section{Backwater curve influence of the reservoir on the channel stability}

In the wiew of wholly arranging Romania's rivers (until 1990) when every discharge will be controled through dams, we draw attention on a case of the influence of backwater curve of reservoirs on channẹl stability. The hydraulic geometry of the Bistrita river, $10 \mathrm{~km}$ upstream of the Izvoru Muntelui Reservoir, is defined by relations: 


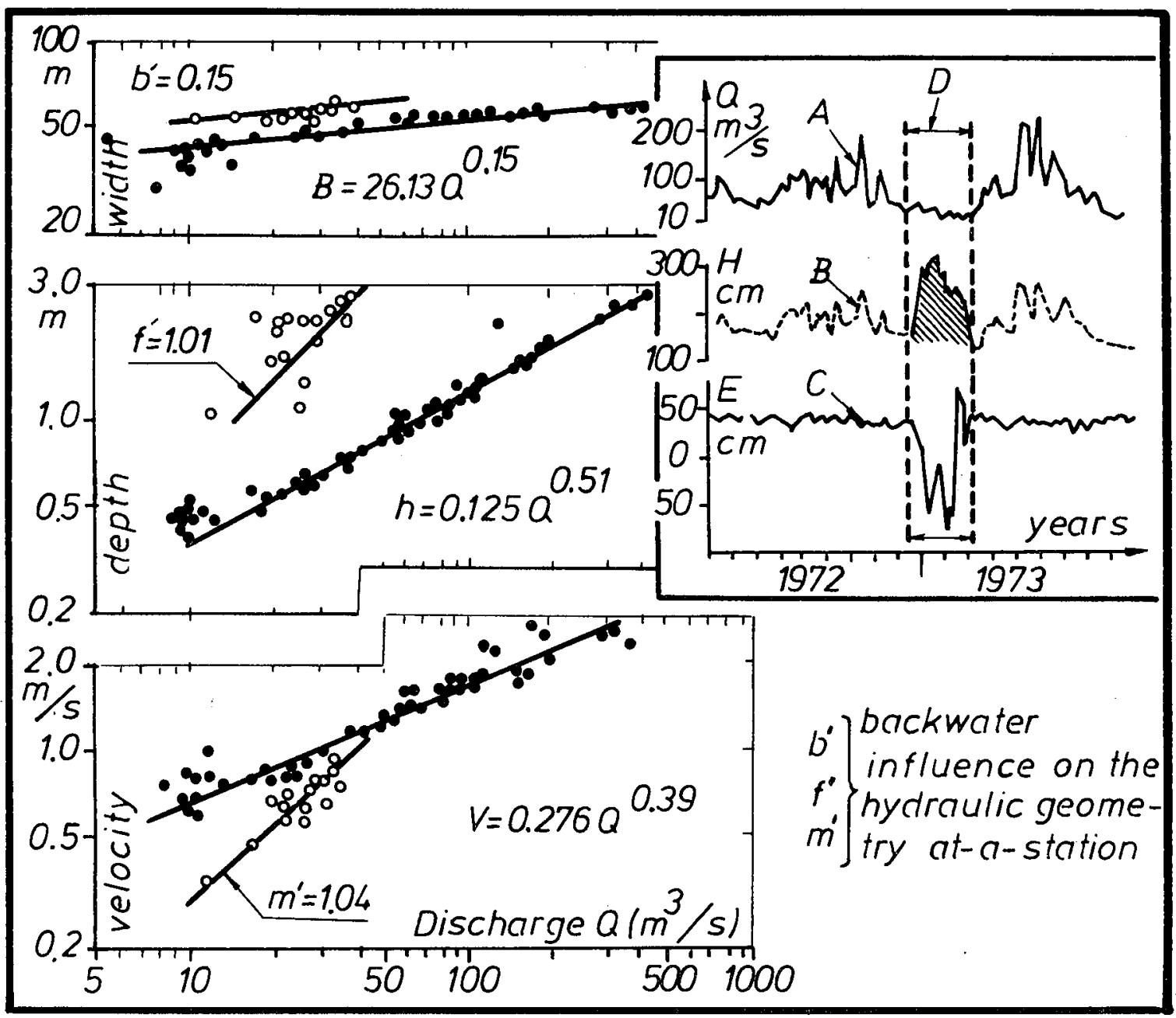

FIG. 4

Changes in hydraulic geometry of Bistrita channel river, above Izvoru Muntelui Reservoir. A. Daily hydrograph; B. Water level variation; C. Channel depth variation; D. The moment backwater phenomenon occuring.

$\mathrm{B}=26.33 \mathrm{Q}^{0.15} ; \mathrm{h}_{\mathrm{m}}=0.125 \mathrm{Q}^{0.51} ; \mathrm{V}_{\mathrm{m}}=0.276 \mathrm{Q}^{0.39}$. The exponents b', $\mathrm{f}^{\prime}, \mathrm{m}^{\prime}$ (fig. 4) represent the change of the hydraulic geometry through water river level uplift, but without a corresponding discharge increase. The variation in time of the discharge water level and channel depth (fig. 4, A, B, C) clearly shows the moment of this change (D). The cause was the up stream mogration of the reservoir level, increased by ice cover and thaws phenomena. The damages caused by such floods, especially when having a longer duration, are well known. In the case of the Bistriţa river it may last 2-3 months. 
DYNAMICS OF ROMANIAN RIVERS

\section{REFERENCES}

ANDREWS, E.D., 1979.-Scour and fill in a stream channel, East Fork River Western Woyming, U.S. Geological Survey Prof. Paper 1117, p. 49.

BATUCĂ, D., 1978.- Aspecte ale morfologiei generale a albiilor din bazinul hidrografic, Hidrotehnica, 23, 6, 121-141.

BĂTUCĂ, D., 1979.- Concepţii energetice în studiul stabilităţii albiilor cursurilor de apă, Hidrotehnica, 8, p. 173-176.

BONDAR, C. and A. PAPADOPOL, 1973.- Caracteristicile evoluţiei în timp a albiei canalului Sulina, Studii de hidrologie, XXXVII, p. 89-108.

COLBY, B.R., 1964.- Scour and fill in sand-bed streams, U.S. Geol. Survey Prof. Paper, 462-D, $32 \mathrm{p}$.

DIACONU, C., 1971.- Probleme ale scurgerii de aluviuni a rîurilor României, Studii de hidrologie, XXXI, $213 \mathrm{p}$.

DIACONU, C., 1973.- Ani caracteristici din punct de vedere hidrologic. Probleme ale determinării. Ani caracteristici pe Dunăre, Studii de hidrologie, XXXVIII, 47-75.

DIACONU, C., A. AVADANEI, S. CIOBANU \& I. MOTEA, 1962.- Despre stabilitatea albiilor rîurilor din R.P.R. în ultimii 30-40 ani, Studii de hidrologie, III, p. 53-63.

DIACONU, C. and co workers, 1971.- Rîurile României, Monografie hidrologică, Bucureşti, 698 p.

HÎNCU, S., 1976.-Regularizarea albiilor rîurilor, Ed. Ceres, Bucureşti, 143 p.

ICHIM, I. \& M. RĂDOANE, 1980.- Unele probleme geomorfologice ale prognozei dinamicii albiilor de rîu. Hidrotehnica (in press).

KNIGHTON, A.D., 1977.- Short-term changes in hydraulic geometry, in River channel changes, ed. K.J. Gregory, 1977, John Wiley and Sons, London, 101-119.

LANE, E.W. \& W.M. BORLAND, 1954.- River bed scour during floods, Am. Soc. of Civ. Engineering Trans., Paper 2712, 1069-1079.

LEOPOLD, L.B., M.G. WOLMAN \& J.P. MILLER, 1964.- Fluvial processes in geomorphology, Freeman and Co., San Francisco, 522 p.

MACKIN, J.H., 1948.- Concept of graded river, Bull. of the Geol. Soc. of America, $59,463-512$.

RĂDOANE, M., M. AMĂRIUCĂI and I. ICHIM, 1979.- Probleme ale dinamicii albiilor unor rîuri din bazinul hidrografic Siret. Studii de hidrologie (in press). 
IONITTA ICHIM, DAN BATUCA, MARIA RADOANE

ROVENTA, V. \& T. NICOLAE, 1975.- Ciclicitatea naturală factor de bază în prognoza de lungă durată. Studii de hidrologie, XLIV, 121-129.

SEIBULESCU, C., G. ENESCU and C. BOTEZ, 1970.- Proiectarea şi executarea canalului de deviere a Jiului. Hidrotehcnica, vol. 17, 7, 337-351.

URZICEANU-ROŞCA, D., 1971.- Unele rezultate ale cercetărilor privind evoluţia albiilor rîurilor în fucţie de regimul hidrologic şi caracteristicile hidraulice. Hidrotehni$c a$, vol. 16, nr. 5, 260-265.

URZICEANU-ROŞCA, D., 1973.- Aspecte metodice privind dinamica albiilor. Studii de hidrologie, XXXVIII, IMH-Bucureşti 183-205.

VELIKANOV, A.M., 1958.- Ruslovoi proţes, Izd. Fiz. Mat. Literatur, Moscova. 